\title{
In the Field
}

\section{Lessons in Labour: Reflections from an Academic Library Co-op Placement}

In September 2019, I began a co-op placement with the Research and Scholarly

Communication team at Western Libraries during ongoing collective bargaining negotiations between the university's librarians and archivists and the administration. My supervisors explained that should the librarians go on strike, myself and other co-op students would continue to work and be paid for fulfilling our assigned duties and projects. Instead of reporting to my designated co-op supervisors—both librarians-I would report to management. This made sense as I was not a member of the union, did not have the same credentials or responsibilities as a librarian, and was not directly affected by the bargaining process. I should have felt relief that, on the surface, little about my placement would change during a strike action. Instead, I felt uneasiness at the prospect of working through a labour disruption. Reflecting on this discomfort, I discovered that I held inner tensions between my competing identities as an activist, a student, and an emerging information professional.

\section{Negotiating Boundaries as a Student Activist}

As a self-identified advocate for labour rights as a form of economic and social justice, I found that my personal values, sense of integrity, and authenticity were challenged by the prospect of the strike. Being expected to come to work even if my colleagues were on the picket line felt wrong to me. The idea of earning a paycheque and performing a role that, strictly speaking, was not a librarian's, but was close enough to blur the lines 
between 'student' and 'professional', was deeply unsettling to me. My fellow co-op students and I were repeatedly reminded that we could access support from nonunionized staff to help us navigate any labour action. I was somewhat comforted by the reassurance, "don't worry, this won't affect your placement;" however, I wanted to worry on my colleagues' behalf. As a way of balancing simultaneous insider and outsider statuses in the midst of a dispute, I considered worry to be the price of inclusion and commitment. Therefore, the activist in me did not want to be protected, but rather wanted to know where the boundaries of my role were, and what options were available to me for negotiating them in professionally respectful ways. I greatly appreciated those colleagues who were open and transparent about their opinions and insights as to where those boundaries lay. I interpreted their transparency as a sign of trust and collegial respect, and it did more to alleviate my inner integrity conflicts than did reassurance alone.

\section{Working-to-Rule as a Student}

As student workers, our relationship to labour issues is moderated through the filter of temporary work for the purposes of learning. As such, we are not eligible for paid sick time, benefits, or incentives, which are often key issues in labour negotiations. We are simultaneously within and removed from the economic and political dynamics and consequences that characterize these disputes. Our emerging professional identities will, therefore, be affected by our relationship to labour, to varying degrees. As I personally tried to reconcile a professional identity with the labour concerns happening around me, I felt torn between conducting myself as a helpful, accommodating, enthusiastic learner and worker-as students are encouraged to be-and taking a 
strong political stance in support of labour. In the midst of this inner struggle, I spoke to a friend who mentioned the job action term work-to-rule. Work-to-rule refers to showing up, adhering strictly to the labour contract, and refusing to do things that go "above and beyond" the conditions of employment. ${ }^{1}$ The prospect of invoking work-to-rule was not entirely outside my comfort zone, but it felt scarier and made me feel more vulnerable than I had expected. I feared being perceived as difficult or uncooperative by management if I adopted a strict work-to-rule position. I attributed this nervousness to an apparent contradiction between my identities as an obliging student employee and a supportive advocate for striking workers.

\section{Managing Personal Vulnerability and Collective Action}

As an advocate for Western's striking librarians, the actions available to me included signing the online letter of support ${ }^{2}$ and participating in the rallies held on campus to raise awareness of the relevant collective bargaining issues. However, when it came to taking these actions, I confess that there were moments where I needed to give myself a push to "put my money where my mouth was." I am often torn between the transformative potential of visibility and a desire for anonymity, particularly around issues of advocacy and change. I suspect that I am not alone in feeling this tension, as during the demonstrations I observed a relatively thin—but vocal and intrepid— presence of Library and Information Science (LIS) student representation. I kept asking myself, why was this not a bigger deal for the LIS community in and around Western?

${ }^{1}$ See the Prairie region of the Public Service Alliance of Canada's website for more about work-to-rule: https://prairies.psac.com/work-rule-what-does-it-mean

${ }^{2}$ A link to the Get Loud! campaign including the University of Western Ontario Faculty Association's form for a letter of support is available at https://www.uwofa.ca/GetLoud 
Perhaps people feel vulnerable making a political stance public. Or perhaps there is confusion about how or why we, as emerging librarians, would need to engage directly with labour issues. While some of this uncertainty can be addressed through course curricula, putting theoretical knowledge into practice typically happens outside of the classroom in work capacities (whether paid or volunteer), as well as in our day-to-day lived experiences. I perceived a missed opportunity to express a collective commitment to solidarity and advocacy by showing up, speaking out, and publicly promoting our professional values. I continue to wonder if I could have done more to advocate for labour rights in this situation and support those directly affected.

\section{Concluding Thoughts}

I am not sure if I fully reconciled my sometimes conflicting identities as an activist, a student, and an emerging information professional in a meaningful way. Perhaps this is because, thankfully, an agreement was reached and strike action was not necessarythis time. ${ }^{3}$ Yet as someone with professional aspirations of academic librarianship, experiencing this intensive process was itself a valuable learning opportunity. It involved wrestling with tough questions: What lessons are we, as students, taking (or not) from the political actions around us, or lack thereof? Are there expectations of students that are inconsistent with us being political actors? What supports and skills do we need to effectively advocate in the field, both for service users and for ourselves as professionals? Answers to these broad critical questions are beyond the scope of this

${ }^{3}$ Details regarding the vote to ratify the collective agreement are outlined briefly in UWOFA's media release dated November 4, 2019 at https://www.uwofa.ca/article/librarians-and-archivists-ratify-agreement-westernadministration 
short piece, but I raise them in an effort to encourage further dialogue, both in the realm of LIS education and training, and in terms of developing our professional identities as librarians. For me, this experience reinforced the fact that mobilizing and advocating for our worth as information professionals is a core component of our education. In the current political climate of budget cuts across institutions, industries, and services, all efforts to advance wage parity, fair benefits, and recognition of our value as skilled professionals will ultimately serve librarianship as a whole.

\section{Janet Allen}

Allen, J. (2020). Lessons in labour: Reflections from an academic library co-op placement. Emerging Library \& Information Perspectives, 3, 208-212. https://doi.org/10.5206/elip.v3i1.8629 